\title{
New strategies to measure and strengthen the social role of business incubators: their application to a Spanish region
}

\section{Eloy Sentana, Reyes Gonzalez*, Jose Gasco and Juan Llopis}

Department of Business Organization,

Faculty of Economics,

University of Alicante,

Alicante, Spain

Email: eloy.sentana@alicante.es

Email:mr.gonzalez@ua.es

Email: jl.gasco@ua.es

Email: juan.llopis@ua.es

*Corresponding author

\begin{abstract}
Business incubators can be defined as a service meant to promote entrepreneurship and firm creation, especially within sectors characterised by a high innovative content. The present paper takes as its starting point a review of previous studies dedicated to the profitability of investments in general, and particularly to that of business incubators, seeking to propose an own method which can make it possible to measure both the economic and the social profitability of business incubators. The subsequent application of this method to the incubators based in a specific Spanish region will lead to the conclusion that incubators are undoubtedly profitable, since society recovers 2.8 euros via taxes from each euro invested. Nevertheless, a number of lacks become visible amongst our findings which should definitely be corrected. Hence our decision to make a number of suggestions aimed at improving both the operation of business incubators and their economic and social profitability levels.
\end{abstract}

Keywords: business incubator; economic profitability; social profitability; entrepreneurship; public investment; Spain.

Reference to this paper should be made as follows: Sentana, E., Gonzalez, R., Gasco, J. and Llopis, J. (2018) 'New strategies to measure and strengthen the social role of business incubators: their application to a Spanish region', European J. International Management, Vol. 12, Nos. 5/6, pp.536-553.

Biographical notes: Eloy Sentana is from 2001 Head of the Economic Promotion Department of the City of Alicante (Spain), where he manages policies of business dynamisation, entrepreneurship diffusion and industrial areas empowerment. His doctoral thesis, 'Economic and social profitability of business incubators in the Valencian Community during the period 20042014', analyses the evolution and impact of business incubators during the reference period, obtaining indicators of profitability. His research evaluates public policies of business promotion to develop proposals to improve the impact of the initiatives proposed by the administration. He has previously published in the journal Entrepreneurship \& Regional Development. 
Reyes Gonzalez is Professor of Business Management and Information Systems at the University of Alicante. Her current research interests are information systems management, e-business, outsourcing processes and public administration management. She has published articles in several journals, e.g. Business Process Management Journal, Information Processing and Management, Information and Management, Information Technology and People, International Journal of Information Management, Information Management \& Computer Security, Industrial Management \& Data Systems, Journal of European Industrial Training, Logistics Information Management, Total Quality Management, and The International Journal of Educational Management.

Jose Gasco is Professor of Business Organisation at the University of Alicante. His current research interests include human resources, information systems outsourcing and public administration management. He has published articles in several journals, namely, Revue Internationale PME, Direction et Gestion des Entreprises, Corporate Communications: An International Journal, The International Journal of Public Sector Management, Business Process Management Journal, Information Processing and Management, International Journal of Information Management, Information Management \& Computer Security, Industrial Management \& Data Systems, Total Quality Management, Journal of European Industrial Training, Information Technology and People, and Logistics Information Management.

Juan Llopis is Professor of Business Organisation at the University of Alicante. Among his current research lines organisational culture, human resources, quality management, information systems management and public administration management stand out. He has published articles in journals such as Information and Management, Total Quality Management, Journal of High Technology Management Research, Corporate Communications: An International Journal, Information Technology and People, Business Process Management Journal, Information Processing and Management, Journal of European Industrial Training, Logistics Information Management Journal, International Journal of Information Management, Information Management \& Computer Security, Industrial Management \& Data Systems, and International Journal of Value-based Management.

\section{Introduction}

Business incubators arise as a service centred on encouraging the creation of firms that can generate high-quality jobs in strategically innovative sectors (Caiazza and Gunasekaran, 2014). The first incubator was set in motion in Batavia (New York), back in 1959, and the implementation of such business incubators has never stopped growing ever since. There were over 1250 business incubators in the USA in 2012, the estimated number of incubators existing all over the world amounting to 7000 (Blanco Jiménez et al., 2015).

It was precisely the European Union that, faced with the need to carry out a deep reform of its firm creation mechanisms, made the decision to encourage the development of incubators (Bank et al., 2016). The aim sought with these initiatives was to undertake new firm creation and employment generation strategies in sectors other than those 
represented by the large corporations which dominated the European scene at the time. Incubators thus began to be driven all around the continent nearly 30 years later than in the USA - as outstandingly exemplified by the UK, which reached a figure of 300 incubators in 2014. The peculiarity of European incubators lies in the great importance of the public sector when it comes to their implementation and management, which has inevitably resulted in a number of particularities that affect their results (Caiazza and Gunasekaran, 2014). Whereas the main aim of US incubators is the creation of innovative firms, since their management characteristically owns a higher level of professionalism and mainly seeks profit goals (Lai and Lin, 2015), the demands for economic profitability are lower in Europe, incubators being understood as a revitalisation instrument and simultaneously as a way to offer local firms spaces at a low cost, which does not always go hand in hand with the theoretical principles of giving support to innovative or diversifying firms (Vaquero García and Ferreiro Seoane, 2013). Nevertheless, a need exists to jointly pursue the economic and social profitability of business incubators because, as several studies have already confirmed in the context of private enterprises, these two goals are by no means incompatible (Muñoz et al., 2015).

Business incubators must provide services placed at the disposal of innovative projects, so that the latter can find a friendly environment to start their initiatives (ZuluChisanga et al., 2016). Furthermore, incubators not only represent a suitable environment to share physical resources but also serve as an excellent breeding ground for the generation of informal working networks, allowing customers and suppliers to get in touch, and building a web of relationships between incubator users through the trust generated by their coexistence (Bouncken et al., 2016). For all these reasons, incubators play a social role, serving as a reference point for professionals and small-sized firms in search of various services which can give a boost to their business, along with a location inside the incubators and some advice on how to set their business activity in motion (Nicolopoulou et al., 2017). Few research works have highlighted this social function of business incubators, though.

Hence why our paper has as its aim to provide the means to assess business incubator profitability; the present study starts from an extensive fieldwork aimed at obtaining information about all the incubators based on a specific Spanish autonomous region - the Comunidad Valenciana [Valencian Community] - but especially at determining the social profitability of business incubators. With this aim in mind, social profitability was defined from the conceptualisation suggested by other authors in a variety of environments, but adapting it to the reality of incubators. The methodology utilised should make it possible to create a sufficiently broad framework to evaluate the social profitability of incubators, thus measuring the extent to which they are efficient for the society that houses them.

The rest of this paper will provide a review of the literature devoted to the measurement and evaluation of business incubators' social profitability, on the basis of which an own model will be proposed to assess that profitability. Below can be found an explanation of the fieldwork methodology followed in the application of that model to cases of incubators located in the Valencian Community. The paper will finish with a summary of the main results obtained as well as the most relevant conclusions drawn from our research work. 


\section{Measurement of the social profitability achieved by a business incubator}

\subsection{General methods to measure profitability}

One of the main concerns in the present paper revolves around finding a method to define the degree of social profitability achieved by an Incubator. A large number of research works have actually dealt with the concept of profitability in what regards private sector firms and activities already (Dilts and Hackett, 2004; Grinols and Mustard, 2001; Stephens and Onofrei, 2012) but, in the case of activities performed by the public sector, the approaches to their analysis developed in later years through the theory related to the evaluation of public services exclusively tried to explain and argue the need for the public sector to become involved in certain areas of private activity (Batley, 1996; Ortega Cachón, 2012; Rainey et al., 1976; Vide et al., 2010). The identification of limits for public intervention in parallel to private activity has traditionally constituted a complex issue at a level with the one being addressed in this study, where we strive to explicitly state the impact derived from implementing an employment creation tool of a publicprivate nature, as are business incubators.

The working methodology designed to assess the activity performed by business incubators is based on three previously existing procedures, the main characteristics of which will be specified below, together with the nuances introduced for the creation of our own analysis model:

\subsubsection{EU cost-benefit analysis guide (European Union, 2003).}

On the one hand, this procedure articulated by the EU to assess the effectiveness of investments made in industrial estates and technological parks defines the steps required to identify the income derived from rentals and land allocation, as well as the repercussion of basic supplies for activity (water, sewer system, electricity, communications, etc.). And, on the other hand, it establishes a procedure to identify the management costs and real expenses involved in the operation of such an infrastructure, for which a time horizon of at least 20 years is considered.

However, despite the possibility for us to use the same expense and revenue methodology, the dimension which serves as the starting point in the case of incubators is much smaller than for industrial estates or technological parks. Hence why the load of structural costs is far lower in business incubators, which only own office buildings or a few industrial premises. To which must be added that industrial estates or technological parks pursue other goals due to their justification as local development instruments (Sentana et al., 2017).

\subsubsection{Social cost-benefit analysis (SCBA)}

Based on the postulates of welfare economics, this analysis suggests formulating consistent projects, not only from a socio-economic point of view but also socially. The goal lies in providing objective information thanks to which it is possible to identify an optimum resource allocation or the implementation of specific policies. The SCBA model serves as a tool which helps to select the best option to be used in the future (Boardman et al., 2006). This does not apply to incubators, since they are services 
which have already been operating for many years. Nonetheless, its postulates were incorporated into our study because the SCBA model can provide a valid rationale for the selection of projects, not only in economic terms but also considering their social impact.

\subsubsection{Social return on investment (SROI)}

This method suggests evaluating the activity from the addition of the so-called 'extrafinancial' value, relating it to the resources invested (social, environmental or socioeconomic value). The aforementioned extra-financial value is not currently reflected on conventional financial accounting with regard to the resources invested in an organisation, a project or an initiative (Nicholls et al., 2012). This methodology collects the assessments made by the different stakeholders about the impact made by such resources and assigns an economic value to all the identified impacts, even if they do not have a market value. This participatory approach permits to identify the way in which a project or organisation creates value and makes it possible to generate an indicator that expresses the actual total value in euros created from each euro invested (ECODES, 2013, Lingane and Olsen, 2004).

In our opinion, an outstanding contribution of this methodology has to do with the need to collate information between the two most important interest groups, the entities promoting incubators and their users, even though for reasons of space, the scope of our work will be confined to describing the direct or indirect impacts induced by the activity carried out by incubators, which are reflected on business activity via taxes.

It is therefore our intention to follow the line of argument shared by these three systems which focus on a cost-benefit analysis meant to monetise the results obtained by incubators, which would provide us with a profit and loss account for the promoting entity (direct impact). Our aim is to go one step further and evaluate the social impact of business incubators through the fiscal repercussion of the economic activity developed both by the incubators as a whole and, above all, by every firm accommodated therein.

\subsection{Models to evaluate business incubator profitability}

In the light of the above, it seems appropriate for us to list the characteristics which the model to be applied needs to fulfil:

(a) It must collect accurate information about every expense- and revenue-generating element associated with the figure of business incubators, insofar as this will allow us to diagnose the economic performance corresponding to the incubator-promoting entity.

(b) It must be suited to the characteristics of the present study, gathering information from the interest groups that hover around incubators. Two broad interest groups were identified for reasons of scope and size of our research paper, namely: promoting entities; and incubator users.

(c) The analysis will have to be widened through a monitoring of the tax impact derived from the activity carried out by firms, which should allow us to ascertain if there is a sufficient profitability level to extend its effects socially, due to the existence of a surplus. 
(d) The model needs to identify the characteristics which optimise a business incubator's profile, so that best practices and good features can be extended to other incubators.

(e) In the case at hand, significant differences arose in the operation of incubators, depending on their origin and individual characteristics but, above all, due to the business environment, the type of management, and the culture existing in the reference regions as far as the goals of business incubators are concerned. This becomes particularly relevant when comparing US and European incubators and influences the way to interpret the results obtained in the studies as well as the references to be analysed.

Bearing in mind all the considerations made in the preceding section, the methods used to measure social profitability will be determined by two factors:

(a) The type of evaluation that we plan to apply, which additionally comprises two dimensions:

1 An internal assessment that will materialise in the implementation of a costbenefit analysis, thus permitting to obtain cash flows from which indicators quantifying economic profitability can result; and

2 An overall assessment in the context of which a comprehensive measurement of incubators' expenses and revenues will be carried out, covering the global action of incubators and their firms in every administration - through their traceability. This will enable us to identify the social impact, being aware of the economic return that can be allocated to purposes external to incubators.

(b) The volume of information that can be obtained and its validity, as well as the inclusion of public subsidies - or not.

The reference for our work can be found in two studies about business incubators made in Spain and focused on their assessment, which additionally comply with the contextualisation parameters described above:

(a) On the one hand, the methodology proposed by Ortega Cachón (2012), where this author uses an application of the traditional return on investment (ROI) calculation and obtains its result drawing a comparison between negative and positive flows over a ten-year period. Thus, negative flows would comprise those generated by the public investments needed to set a business incubator in motion. In turn, positive flows would be the part of turnover corresponding to the new firms that have helped to avoid the closure of incubators, which also implies giving back its contributions to the public administration through tax revenues. Ortega-Cachón's work is limited to six incubators located in the Madrid province. The method materialises in a model, the result of which generates a ratio where total revenues (those collected via taxes plus the ones coming from rentals) are divided by total expenses (investment and incubator maintenance).

(b) Complementarily, the work developed by Ferreiro Seoane (2013) puts forward a methodology developed from the fiscal balance, albeit adapted to business incubators. This author approaches the calculation on the basis of the Spanish Autonomous Regions' fiscal balance with the aim of identifying the amount that 
results from the total expenses incurred by each region in its territory minus what that specific region provides to the Public Treasury and, on the other hand, the already mentioned European Union methodology (2003). As for the calculation of the amounts paid and received, Ferreiro Seoane (2013) calculates the income collected by the Administration as a whole, including the indirect taxes (VAT) as well as the direct ones (Corporate Tax, Income Tax and Social Security contributions) obtained from the firms accommodated in incubators. The aforementioned author determines the costs through the calculation of the operating and maintenance expenses corresponding to incubators over a five-year period.

Its final result stems from a comparison between the public resources allocated to the setting in motion and operation of incubators (public contributions and subsidies as well as property amortisation) and the tax revenues generated by the workers and entrepreneurs accommodated therein.

Both methods seek to try and calculate how many euros society obtains from each euro invested in incubators, both for their creation and for their maintenance, drawing a parallel with the traditional calculation of business profitability. The most important difference lies in the way to count the investment concepts and entries, the expenses and revenues, and also in the decision to include public subsidies - or not. Furthermore, the ROI calculation made by Ortega Cachón (2012) takes into account not only the tax revenues generated by the workers and entrepreneurs currently belonging to the incubator but also the income associated with those who have already left it, which in our view matches the actual philosophy of incubators: to promote innovative activities whose start and setting in motion is made easier and which, instead of seeking to stay in the Incubator forever, actually plan to project themselves towards the outside, which is where the investment and the commitment made by the Administration to support the project must provide a return.

These two methodologies exclude other taxes such as the Spanish tax on the Economic Activities of firms (Business Tax) because neither the two aforementioned studies nor the present one refer to any single firm accommodated and constituted as a company with a turnover exceeding $1,000,000$ euros. ${ }^{1}$

\section{Construction of an own calculation model}

In the light of the documentation and studies examined, a decision was made to incorporate a holistic evaluation model. It does not make much sense to assess incubators as a merely economic activity when, in fact, their extra-monetary (social and territorial) repercussions very often constitute their raison d'être (Nicolopoulou et al., 2017) Their actual definition as a delivery of services at a cost lower than that of the market for those individuals who decide to create an incubator stems from the premise that these projects entail losses for the promoting entity. However, public sector activities are hardly ever justified by the direct economic return that they bring back to the common treasury; it is the social benefits brought by such activities that matter most (Wang et al., 2016).

It is also necessary to place the emphasis on an overall assessment of the results obtained by incubators (Voisey et al., 2006), starting from the calculation of the expenses or the economic resources available for entities to keep them operational, considering the contributions made by entrepreneurs in respect of accommodation, plus the public 
financial aids and subsidies, along with some indirect revenues - fiscal ones in this casewhich directly impact on all public administrations and collaterally on incubators. On the basis of this economic profitability evaluation model, an effort will be made to measure the result of each incubator from the difference between expenses and revenues, seeking to achieve an aggregate final assessment of social performance, taking into account the expenses/costs needed for the operation of incubators, as well as the revenues directly and indirectly generated via taxes through direct activities (the actual functioning of BIs) and indirect ones (the impact caused by the firms accommodated therein).

Below can be found a breakdown of the concepts included in the calculation of social profitability:

- The consideration as EXPENSES or allocated resources is given to the public contributions required for the operation of incubators, which materialise through the economic resources provided by the owning entities in three items:

1 Annual amortisation of the properties where the incubator is located

2 Public subsidies and aids provided by the entities themselves to develop the activity in question (supplies, staff, operating costs, etc.).

3 The contributions made by entities to redress the imbalance between incubators' operating revenues and expenses.

- Instead, the consideration as REVENUES is given to the ones which entities, and in turn all public administrations (mainly Treasury and Social Security) obtain from the activity performed in incubators through the income derived from taxes and social security contributions, both corresponding to incubator workers and from entrepreneurs and their employees, including three items:

1 Income Tax (IRPF) applied to incubator workers, to entrepreneurs not constituted as companies, and to the employees of entrepreneurs, from the gross monthly salary specified in the survey and following the deduction tranches stipulated by the Spanish Tax Agency for 2014.

2 Social security. A distinction between two types of contributors was drawn within social security contributions, namely: those who make them through the so-called Special Framework for self-employed workers (98.3\% of those accommodated in incubators) for which a calculation basis was established on the minimum contribution of $264.4 €$; and the remaining workers, including both the actual employees of incubators and those hired by entrepreneurs, whose contributions are all made within the General Social Security Framework, with an average $6.3 \%$ contribution being applied on their salary. It was not deemed appropriate to include the income derived from corporate tax within the calculation method because the impact that firms located in incubators have on this tax is hardly significant, to which must be added that the interviews made failed to supply reliable information which could be complemented by additional sources (Trade Registry), insofar as many of the firms had no legal obligation to present their accounts on the date when the study took place.

3 Other revenues. As could be the direct contributions associated with other activities developed in incubators: rental of common facilities to external firms and entities, organisation of events or consultancy services, amongst others. 


\section{Methodology}

As previously highlighted in the introduction, an extensive fieldwork serves as the basis for the present study to collect information about all the business incubators located in the Valencian Community - a south-eastern Spanish autonomous region made up of three provinces (Alicante, Valencia and Castellón) with 5 million inhabitants and 542 municipalities. The procedure suggested to carry out the research work consisted in preparing a census of all the active Valencian-Community-based business incubators. The powers related to economic and industrial promotion, as well as the actions oriented to employment generation, fall upon the Generalitat Valenciana (Government of the Valencian Community) and not upon the Central State. It is the fourth Spanish region in terms of GDP generation, its main productive sectors being: agriculture (basically around citrus fruit growing); industry (footwear, toys, textiles, ceramics, chemicals and an important car-manufacturing plant); and an incipient culture in favour of innovative enterprises under the auspices of Technological Institutes and Universities.

The information needed to develop our study was obtained in two stages: qualitative and quantitative. The technique used to collect information during the qualitative stage was an in-depth interview carried out face to face or via telephone (in the case of the Castellón province) with the directors and/or managers of the 43 incubators located in the Valencian Community. Two of them were not available and one did not properly complete the survey questionnaire that had been sent to him, which means that our information refers to a total population of 40 out of 43 existing incubators $(93.02 \%)$.

Instead, the information obtained in the quantitative study stems from a closedquestion survey addressed to business projects leaders and to the directors or managers of the firms currently accommodated in incubators, for which purpose an online questionnaire was used. The interest during this second stage focused on discovering the profile of entrepreneurs accommodated in incubators (which lies beyond the scope of the present paper) but also on comparing the opinions expressed by directors and managers. Seeking to carry out a qualitative analysis of incubators, a process was undertaken that led to identify 394 firms accommodated in incubators - 183 of which answered the survey questionnaire (statistical error $+/-5.5$, confidence interval $95.5 \%$, and $p=q=0.5$ ). The information from these firms accommodated in incubators helped us to confirm the data provided in the qualitative phase. Those cases where not all the information was available forced us to use secondary information sources (e.g. databases, reports, previous studies, web pages or websites) through which not only the information collecting process could be completed but also estimates and assessments could become more accurate. In any case, the study results provided will mainly focus on the quantitative outcomes.

\section{Results}

\subsection{Resources and revenues generated in incubators}

The application of the previously described methodology, where the aggregate calculations of the current and future expenses and revenues via taxes were carried out, revealed that the public administration recovers $2.8 €$ from each euro invested. The 
analysis about the composition of this result showed us that 2,855,225€ will be collected through direct and tax-related income, which required the allocation of $1,006,488 €$ by public entities for the operation of business incubators (Table 1).

Table 1 Resources and revenues generated by Valencian-Community-based incubators (2014)

\begin{tabular}{|c|c|c|c|c|c|c|c|}
\hline \multirow{2}{*}{\multicolumn{2}{|c|}{ Incubators }} & \multicolumn{3}{|c|}{ Revenues } & \multirow{2}{*}{$\frac{\text { Resources }}{\epsilon}$} & \multirow{2}{*}{$\frac{\text { Result }}{\epsilon}$} & \multirow{2}{*}{$\begin{array}{c}\text { Ratio }= \\
\text { Revenues/ } \\
\text { Resources }\end{array}$} \\
\hline & & $\epsilon$ & $\%$ Work. & $\%$ Firms & & & \\
\hline \multirow{4}{*}{ Ownership } & Town Councils & 567,928 & 9.8 & 90.2 & 336,476 & 231,452 & $1.7 €$ \\
\hline & $\begin{array}{l}\text { Chambers of } \\
\text { Commerce }\end{array}$ & $1,092,810$ & 4.3 & 95.7 & 311,166 & 781,644 & $3.5 €$ \\
\hline & BICs & 611,507 & 5.5 & 94.5 & 203,767 & 407,740 & $3.0 €$ \\
\hline & Universities & 582,982 & 9.0 & 91.0 & 155,079 & 427,903 & $3.8 €$ \\
\hline \multirow{4}{*}{$\begin{array}{l}\text { Sectorial } \\
\text { Group }\end{array}$} & $\begin{array}{l}\text { G1 } \\
\text { Technological }\end{array}$ & $1,240,132$ & 7.9 & 92.1 & 463,209 & 776,923 & $2.7 €$ \\
\hline & G2 Industrial & 418,962 & 4.7 & 95.3 & 58,750 & 360,212 & $7.1 €$ \\
\hline & G3 Services & $1,196,130$ & 6.0 & 94.0 & 484,529 & 711,602 & $2.5 €$ \\
\hline & Total & $2,855,226$ & 6.6 & 93.4 & $1,006,488$ & $1,848,738$ & $2.8 €$ \\
\hline
\end{tabular}

Notwithstanding the above, this aggregate result does not homogeneously represent the data reflected for each one of the incubator groups examined, between which a number of remarkable differences appear. If an in-depth analysis is performed according to the promoting entity that runs the incubator, those promoted by Town Councils offer the worst results, with an expense-income ratio of $1.7 €$, a significantly lower figure than that shown by incubators managed by Chambers of Commerce (3.5€), European $\mathrm{BICs}^{2}(3.0 €)$ or Universities (3.8€).

Amongst the reasons which can be adduced to explain such differences stands out the fact that quite a few incubators promoted by local entities were set in motion without having previously carried out a study about their suitability in the municipality which, together with the evolution of the crisis undergone during the last few years and the lack of commercialising actions aimed at disseminating the advantages that being located in an incubator can bring to a firm, ultimately resulted in the low occupancy levels generally achieved by incubators.

With regard to sectorial orientation, the best global result corresponds to incubators associated with industrial firms, since a return of 7.1 euros is foreseen for each euro invested. This has to do with the lower operating costs involved in such infrastructures because, while promoting entities usually assume the running costs (electricity, water or cleaning) in incubators which accommodate offices, those operating expenses are assumed by firms when it comes to industrial incubators. As a matter of fact, the operating expenses of industrial incubators are 17 times lower than those incurred by service incubators or 7 times lower than the expenses assumed by technological incubators.

\subsection{Business incubators as employment promoters}

One of the main social functions performed by business incubators consists in helping job creation; that is why it seems interesting to measure whether the accommodated firms 
generate employment or not and if they do so to a greater or lesser extent than the average of national firms.

Less than $5 \%$ of the firms listed in the trade registry had been constituted with a staff size of more than five employees. As for firms accommodated in incubators, $9.2 \%$ of them have more than five employees. This is undoubtedly a good indicator which shows that entrepreneurs located in incubators generate more jobs on average than those who do not want - or cannot choose - to be accommodated therein. Nevertheless, the proportion of businesses at an initial stage (0-42 months) with no employees is $53 \%$, a similar percentage to that obtained in España GEM (2014) - 54.7\% - and $62.8 \%$ of the consolidated firms do not have any employees, a percentage that largely exceeds the one found in the España GEM (2014) - 40.3\%.

Table 2 shows the employment generated in incubators according to their ownership and sectorial orientation, as well as the type of entrepreneur, paying special attention to their years of operation.

Table 2 Persons linked to entrepreneurial activities in Valencian-Community-based incubators (2014)

\begin{tabular}{lccccc}
\hline \multirow{2}{*}{ Criteria } & \multicolumn{2}{c}{ Persons linked } & Women & \multicolumn{2}{c}{ Distribution (\% rows) } \\
\cline { 2 - 6 } & Mean & Stan. Dev. & \% / total & Partners-workers & Employees \\
\hline Town Councils & 2.7 & 2.993 & 23.2 & 59.4 & 40.6 \\
Chambers of & 2.6 & 4.850 & 25.6 & 52.6 & 47.4 \\
Commerce & 2.3 & 1.842 & 15.5 & 72.5 & 27.5 \\
BICs & 4.2 & 4.191 & 15.8 & 60.4 & 39.6 \\
University & \multicolumn{5}{c}{ Ownership } \\
\hline & 3.1 & 3.230 & 16.5 & 64.7 & 35.3 \\
\hline G1 Technological & 2.6 & 3.442 & 9.1 & 61.8 & 38.2 \\
G2 Industrial & 2.7 & 4.343 & 27.1 & 54.1 & 45.9 \\
G3 Services & \multicolumn{5}{c}{ Type of entrepreneur } \\
\hline & 2.2 & 1.485 & 18.5 & 100.0 & \\
\hline Entrepreneur & 5.1 & 5.801 & 25.0 & 45.5 & 54.5 \\
Incipient & 2.9 & 4.808 & 19.7 & 52.3 & 47.7 \\
New & 2.2 & 2.320 & 22.8 & 62.8 & 37.2 \\
Consolidated & $\mathbf{2 . 1}$ & $\mathbf{3 . 9 3 4}$ & $\mathbf{2 1 . 7}$ & $\mathbf{5 2 . 4}$ & $\mathbf{4 7 . 6}$ \\
\hline Total & &
\end{tabular}

In relation to this last aspect, four groups can be identified following Gómez Gras et al. (2013) and España GEM (2014): Entrepreneurs, i.e. those individuals who have expressed their intention to set up a business, including self-employed workers here; Incipient Activities, characterised by having less than three months of operation paying some kind of wage-earner; New Activities, which have been paying some salary for three to forty-two months; and Consolidated Activities, with over forty-two months of operation. 
As seen in Table 2, incipient activities have a higher average number of persons linked to the project (5.1) and additionally reveal an outstanding weight of employees in the distribution between partners and employees. However, as the firm's years of operation increase, not only its staff size diminishes (going from 2.9 persons in new activities to 2.2 in consolidated activities) but also the partner-employee distribution, which moves down from $47.7 \%$ of employees in new activities to $37.2 \%$ in consolidated ones. Amongst the possible explanations for this situation might be the lack of experience in human resource management that characterises incipient initiatives, along with the problems derived from economic recession in recent years, which led consolidated firms to readjust their teams so that they could survive.

It similarly becomes evident that the percentage of female presence is low in whatever sectorial orientation and life stage of firms, even lower than the ratios collected in España GEM (2014), according to which 4 out of 10 entrepreneurs were women - the figure hardly reached 2 in our study.

\subsection{Economic activities developed in Valencian-Community-based incubators}

It is important to analyse the economic activities promoted by business incubators, since their support to innovative and high-added-value sectors will be a reflection of their social profitability. Hence why the economic activities developed in the incubators under study will be examined in this section.

Ever since 2008, the economic crisis in Spain has had negative effects in every productive sector - particularly in industry and construction. According to España GEM (2014), entrepreneurial activity in Spain has clearly veered towards activities related to the tertiary sector since 2008: $33.5 \%$ of projects at an initial stage (from 0 to 42 months of operation) and $46.3 \%$ of consolidated activities (over 42 months of operation) concentrated in industrial and transforming sectors - especially in the construction sector - in 2008. These figures went down to $19.6 \%$ in projects at an initial stage and $35.6 \%$ for consolidated activities in 2014.

Table 3 Economic activities developed in Valencian-Community-based incubators (2014)

\begin{tabular}{lcc}
\hline Economic activities & $N$ & $\%$ \\
\hline Manufacturing industry & 16 & 8.7 \\
Construction & 9 & 4.9 \\
Wholesale and retail trade & 30 & 16.4 \\
Information and Communications & 34 & 18.6 \\
Professional, scientific and technical activities & 56 & 30.6 \\
Services: administrative and professional & 27 & 14.8 \\
Other activities & 11 & 6.0 \\
\hline Total & $\mathbf{1 8 3}$ & $\mathbf{1 0 0 . 0}$ \\
\hline
\end{tabular}

The activities currently developed by entrepreneurs accommodated in Valencian incubators accordingly tend more towards the tertiary sector, both at their initial stages and in consolidated activities (see Table 3 ). This sector comprises $70 \%$ of activities, and the following subsectors can be highlighted: 
1 Information and communications (18.6\%). Especially activities related to programming and IT consultancy, above all, development of applications for mobile phones and data processing, hosting and treatment of Web portals. It is additionally worth stressing that $85 \%$ of new business activities use the Internet as their only commercialisation structure and channel.

2 Professional, scientific and technical activities (30.6\%). This one stands out, together with information and communications, for being the main activity group towards which entrepreneurs are oriented. The most significant activities revolve around technical consultancy in engineering, with special attention to businesses aimed at improving the energy efficiency of firms and individuals, business management consultancy, and agencies dedicated to marketing, communication and advertising.

3 Other services: administrative and personal (14.8\%). The trend within this third group is to offer management and/or advisory services related to sports activities, those focused on physical maintenance (a special mention deserves to be made of dietetics and nutrition), as well as business training, and particularly coaching.

4 Other activities (6\%). This group includes a wide range of activities, amongst which road-borne goods transport and courier services stand out for their importance.

\section{Discussion and conclusions}

The social impact caused by business incubators, assessed from the effect of taxation in the different public administrations, allows us to state that the creation of firms is already generating positive impacts on the environment where they operate. The contribution made by incubators must thus not be understood as an expense, but rather as an investment, since public funds are applied to projects which -if properly managed- can bring a positive return in the middle and long term, which amounts to $2.8 €$ recovered from each euro invested. It was additionally checked that incubators accommodate firms which create employment at above-average levels, and that those accommodated firms belong to high-added-value or innovative sectors, such as information and communications, as well as professional, scientific and technical activities which contribute to a change in the productive model from one based on industry and the building sector (in the Spanish case) to another one based on sectors which can prove more sustainable in the long term. There is still a margin to increase the social impact of incubators; an enhancement of their management should contribute not only to create a larger number of firms but also to develop them in a more suitable way.

As for the methodology suggested to assess the social profitability of incubators, it allows us to make the period during which expenses are generated fit in with that of revenues, so that a fit which is consistent over time in economic terms can be achieved. This gives incubators the chance to be economically profitable, since they can make up for their contributions and expenses in firms via tax revenues. The reason for this lies in the fact that these firms generate fewer revenues in their initial stage than in their maturity, when they are usually no longer located in the incubator, from which they benefited in the stage when they were at their weakest. 
As seen above, business incubators generate $2.8 €$ on average from each euro invested in them. It is worth highlighting, though, that the entity making the investment is not the same that receives the subsequent revenues, which results in an asymmetrical behaviour. This study reflects that, while it is local entities, universities, chambers of commerce and European BICs that finance the setting in motion of incubators either with their resources or through national or supranational incentive programmes, the surpluses on investment which are recovered via taxes are collected by the State Administration, which does not have a compensation mechanism or an incentive for promoting entities. It seems evident that a compensation mechanism should exist to encourage those entities which carry out good work in incubators -generating innovative firms which can emerge from them within a reasonable period of time, creating jobs and diversifying the industrial fabric, amongst other things. The possibility to reallocate these resources by means of interadministrative compensation mechanisms, with a format resembling the one used for the Fondo de Compensación Interterritorial [Interterritorial Compensation Fund], ${ }^{3}$ would allow for a reversal of a situation like the present-day one, which is clearly unfair in terms of economic effort for promoting entities.

Even though it would somehow be necessary, on the one hand, to introduce that mechanism aimed at compensating revenues for their social redistribution, on the other hand, it seems clearly advisable to incorporate incentives into private investment when promoting business incubators. A suggestion of the formats that this fiscal compensation should adopt can be found in the work of Klemm (2010), who concludes that the incentives to favour R\&D have undeniably positive effects. This allows us to infer that a joint effect to stimulate investment in the innovative firms of incubators would definitely have a positive impact too.

It also becomes quite clear, following this same author, that if the aim sought consists in promoting the creation of innovative firms, many of which still find themselves at an incipient stage, and considering that they are very often not supervised by expert Business Angels, it apparently does not seem suitable to focus the investing pressure merely on profitability, which suggests the need to assess the possibility to combine the actual incentives to profitability with tax bonuses. These incentives have proved effective according to Moretti and Wilson (2014), who studied state incentives in the sector of biotechnological firms, estimating that such business organisations had grown by $15 \%$, whereas the decrease of user capital cost by $10 \%$, induced by an increase of tax incentives for R\&D, raises the number of leading firms in the sector by $22 \%$. In contrast to this optimistic study, other authors (Román et al., 2013) argue that these incentives, applied to an entrepreneurs' profile may be ruined by other variables present in the environment.

Amongst these variables stand out a rigid labour legislation or the lack of a culture that can help the unemployed become entrepreneurs able to hire other people out of work. These authors additionally refer to the concept of social capital with which they seek to highlight the benefits offered by the contact networks which are likely to arise between firms. As can be checked, all these factors not only determine the extent to which incentive policies will prove successful but also constitute an essential part of business incubators, which leads us to infer that the application of incentives within such a favourable environment as incubators is yet another key element for their future success.

A relevant factor in incubators is their orientation towards firms with an aboveaverage number of innovative components. This implies recognising that incubators exert 
a driving force upon a certain typology of firm (in our study, information and communications $-18.6 \%$ - as well as professional, scientific and technical activities $30.6 \%$ ). It seems only logical to suggest that a society where changes of paradigms and economic models are supported should give a boost to those elements which can foster such activities. Assuming the hypotheses posed by Stiglitz (1992) in relation to the role played by the Administration in the private sector, the allocation of a greater volume of public resources meant to promote the creation of more innovative firms would appear absolutely justified.

An additional conclusive element would be the need to rethink the role of incubators in the current format. Based on the American experience, where incubator managers have a much more proactive behaviour when it comes to driving firms so that they can grow, consolidate and eventually leave the facilities (Al-Mubaraki and Wong, 2011; Duff, 1994; Marchis, 2011), it becomes important to determine, as well as to carry out, a more in-depth monitoring of the characteristics and evolution of the firms accommodated in incubators, thus speeding up their rotation.

One of the indicators that best measures the effectiveness achieved by a business incubator is its occupancy rate. The data obtained in the present study show an occupancy rate of $65.5 \%,{ }^{4}$ which would suggest that the resources available to incubators are not being optimised and, therefore, incubators are not being profitable (Ferreiro Seoane, 2013). In other words, incubators do not act as a useful tool to accommodate innovative firms: there is either an oversupply of spaces or an inability on the part of incubators to make known the advantages that being in one of them can bring as a starting point for projects at an embryonic stage.

As for incubators' ability to promote female employment, the absolute results obtained do not seem to leave room for doubt concerning the need to undertake alternative initiatives to foster women's entrepreneurship. The under-representation of women in incubators may come as a reflection of a previous casuistry; since incubators are oriented towards innovative and technological firms, the smaller female presence in these technical fields is likely to result in a lower number of candidatures to incubators. According to the data provided by the report on Spanish University (Hernández Armenteros and Pérez García, 2016), despite globally being a majority at universities, women have a limited presence in technical or engineering degrees (electronics 14.67\%; mechanics $13.70 \%$; computer science $10.90 \%$ ). It can thus be concluded that the female presence in incubators largely matches their presence in the university degrees that include the contents most often demanded by incubators. One may question whether the implementation of specific incentives would result in a greater presence of women in entrepreneurial activities (Gatrell and Cooper, 2008; Walker and Joyner, 1999). Nevertheless, this question must actually be approached from an overall perspective: economic incentives are positive but they need to be accompanied by other reforms such as putting maternity and paternity leaves on a level and other reconciliation measures.

A number of recommendations to enhance the value of business incubators can be drawn from these results, namely:

- Compensating the entities that finance and support the creation of incubators with part of the income via taxes generated from them.

- Promoting the task carried out by incubators, insofar as they exert a driving effect on the innovative economic activities advocated in the new economic models and paradigms. 
- Rethinking the role of incubators so that they can follow the evolution of the incubated firms, speeding up their rotation.

- Adapting the demand of facilities offered by incubators to make them profitable.

- Giving a boost to women's role in the entrepreneurial activities performed in incubators.

The present paper has limitations too, as is the essentially descriptive nature of the method applied to the processing of data -additionally confined to a single Spanish region. This circumstance makes it difficult to generalise our results. All in all, it seems to us that this study provides important results in what regards the economic-social justification for business incubators and offers a number of suggestions that should be followed both by the public authorities in charge of business promotion and by entrepreneurs, and consequently makes a significant contribution to such a fruitful research area as business entrepreneurship. Thus, the present paper clearly provides support to the studies undertaken at an international level which have focused on assessing not only the economic profitability of business incubators but also the social one, and follows along the lines of other European studies dedicated to the social and innovative values of business incubators (Aerts et al., 2007).

\section{Acknowledgement}

The authors would like to express their gratitude both to the editor and to the two anonymous reviewers for all their helpful suggestions.

\section{References}

Aerts, K., Matthyssens, P. and Vandenbempt, K. (2007) 'Critical role and screening practices of European business incubators', Technovation, Vol. 27, No. 5, pp.254-267.

Al-Mubaraki, H.M. and Wong, S.F. (2011) 'How valuable are business incubators? An illustration of their performance indicators', European, Mediterranean \& Middle Eastern Conference on Information Systems 2011, Athens, Greece, pp.756-765.

Bank, N., Fichter, K. and Klofsten, M. (2016) 'Sustainability-profiled incubators, regional factors and the recruiting of tenants', RENT XXX Conference, Antwerp University, Belgium, 16-18 November.

Batley, R. (1996) 'Public-private relationships and performance in service provision', Urban Studies, Vol. 33, Nos. 4/5, pp.723-751.

Blanco Jiménez, F.J., De Vicente Oliva, M., Manera Bassa, J. and Polo García-Ochoa, C. (2015) Los servicios que prestan los viveros de empresas en España [The services provided by business incubators in Spain], Ranking 2015, Funcas, Madrid.

Boardman, A.E., Greenberg, D.H., Vining, A.R. and Weimer, D.L. (2006) Cost-Benefit Analysis: Concepts and Practice, Prentice Hall, Upper Saddle River, NJ.

Bouncken, R.B., Pesch, R. and Reuschl, A. (2016) 'Copoiesis: mutual knowledge creation in alliances', Journal of Innovation and Knowledge, Vol. 1, No. 1, pp.44-50.

Caiazza, R. and Gunasekaran, A. (2014) 'Benchmarking of business incubators', Benchmarking: An International Journal, Vol. 21, No. 6, pp.1062-1069. 
Dilts, D.M. and Hackett, S.M. (2004) 'A systematic review of business incubation research', The Journal of Technology Transfer, Vol. 29, No. 1, pp.55-82.

Duff, A. (1994) 'Best practice in business incubator management', AUSTEP Strategic Partnering Pty, Booragoon, Australia.

ECODES (2013) Retorno Social de la Inversión (SROI) [Social return on Investment (SROI)], Available online at: http://ecodes.org/responsabilidad-social/retorno-social-de-la-inversionsroi\#.VlWI-Pkvfcs

España GEM (2014) ‘Global Entrepreneurship Monitor’, Informe GEM España, Vol. 18.

Ferreiro Seoane, F.J. (2013) Los Viveros de empresas en Galicia: una estrategia generadora de riqueza [Business Incubators in Galicia: A Strategy that generates Wealth.]. Universidade da Coruña. Available online at: http://dialnet.unirioja.es/servlet/tesis? codigo $=41063$

Gatrell, C.J. and Cooper, C.L. (2008) 'Work-life balance: working for whom?' European Journal of International Management, Vol. 2, No. 1, pp.71-86.

Gómez Gras, J.M., Mira Solves, I., Galiana Lapera, D. and Estrada de la Cruz, M. (2013) Informe GEM Comunidad Valenciana 2013 [GEM Report Valencian Community 2013]. Available online at: http://innovacionumh.es/GEM/2013/GEM.pdf

Grinols, E.L.E. and Mustard, D.B.D.B. (2001) 'Business profitability versus social profitability: evaluating industries with externalities, the case of casinos', Managerial and Decision Economics, Vol. 22, Nos. 1-3, pp.143-162.

Hernández Armenteros, J. and Pérez García, J.A. (2016) La Universidad española en cifras [Spanish University in figures], CRUE. Available online at: http://www.crue.org/ Documentos\%20compartidos/Publicaciones/Universidad\%20Espa $\% \mathrm{C} 3 \%$ B1 ola $\% 20 \mathrm{en} \% 20 \mathrm{cifr}$ as/UEC_14-15.pdf

Klemm, A. (2010) 'Causes, benefits, and risks of business tax incentives', International Tax and Public Finance, Vol. 17, No. 3, pp.315-336.

Lai, W.-H. and Lin, C.-C. (2015) 'Constructing business incubation service capabilities for tenants at a post-entrepreneurial phase', Journal of Business Research, Vol. 68, No. 11, pp.2285-2289.

Lingane, A. and Olsen, S. (2004) 'Guidelines for social return on investment', California Management Review, Vol. 46, No. 3, pp.116-135.

Marchis, G. (2011) 'Fundamentals of business incubator development', EIRP Proceedings. Available online at: http://www.proceedings.univ-danubius.ro/index.php/eirp/article/ download/955/874

Moretti, E. and Wilson, D. J. (2014) 'State incentives for innovation, star scientists and jobs: evidence from biotech', Journal of Urban Economics, Vol. 79, pp.20-38.

Muñoz, R.M., Sanchez de Pablo, J.D. and Peña, I. (2015) 'Linking corporate social responsibility and financial performance in Spanish firms', European Journal of International Management, Vol. 9, No. 3, pp.368-383.

Nicholls, J., Lawlor, E., Neitzert, E. and Goodspeed, T. (2012) A Guide to Social Return on Investment. Available online at: http://www.thesroinetwork.org/publications/doc_download/ 445-the-sroi-guide-spanish

Nicolopoulou, K., Karataş-Özkan, M., Vas, C. and Nouman, M. (2017) 'An incubation perspective on social innovation: the London Hub - a social incubator', R\&D Management, Vol. 47, No. 3, pp.368-384.

Ortega Cachón, I. (2012) Medición del impacto socioeconómico y evaluación de las políticas públicas de apoyo a emprendedores e impulso de la creación de empresas [Measurement of the Socio-Economic Impact and Evaluation of Public Policies aimed at Supporting Entrepreneurs and Driving the Creation of Companies], Doctoral Thesis, Universidad Rey Juan Carlos I. Madrid.

Rainey, H.G., Backoff, R.W. and Levine, C.H. (1976) 'Comparing public and private organizations', Public Administration Review, Vol. 36, No. 2, pp.233-244. 
Román, C., Congregado, E. and Millán, J. M. (2013) 'Start-up incentives: entrepreneurship policy or active labour market programme?' Journal of Business Venturing, Vol. 28, No. 1, pp.151-175.

Sentana, E., González, R., Gascó, J. and LLopis, J. (2017) 'The social profitability of business incubators: a measurement proposal', Entrepreneurship \& Regional Development, Vol. 29, Nos. 1/2, pp.116-136.

Stephens, S. and Onofrei, G. (2012) 'Measuring business incubation outcomes: an Irish case study', International Journal of Entrepreneurship and Innovation, Vol. 13, No. 4, p.277.

Stiglitz, J.E. (1992) Economics of the Public Sector, Norton, New York.

Unión Europea (2003) Guía del análisis coste-beneficio de los proyectos de inversión. [Guide to the cost-benefit analysis of investment projects]. Available online at: http://ec.europa.eu/ regional_policy/sources/docgener/guides/cost/guide02_es.pdf.

Vaquero García, A. and Ferreiro Seoane, F.J. (2013) Análisis regional de los viveros de empresa. [Regional analysis of business incubators], Smart Regions for a Smarter Growth Strategy, 21-22 November, Oviedo, Spain. Available online at: http://www. reunionesdeestudiosregionales.org/Oviedo2013/htdocs/pdf/p623.pdf.

Vide, R.K., Bobek, V., Cancer, V., Perko, I. and Hauptman, L. (2010) 'The efficiency of entrepreneurship policy support for the internationalisation of SMEs: the case of Slovenia', European Journal of International Management, Vol. 4, No. 6, pp.644-664.

Voisey, P., Gornall, L., Jones, P. and Thomas, B. (2006) 'The measurement of success in a business incubation project', Journal of Small Business and Enterprise Development, Vol. 13, No. 3, pp.454-468.

Walker, D. and Joyner, B. E. (1999) 'Female entrepreneurship and the market process: genderbased public policy considerations', Journal of Developmental Entrepreneurship, Vol. 4, No. 2, pp.95-116.

Wang, H., Tong, L., Takeuchi, R. and George, G. (2016) 'Corporate social responsibility: an overview and new research directions thematic issue on corporate social responsibility', Academy of Management Journal, Vol. 59, No. 2, pp.534-544.

Zulu-Chisanga, S., Boso, N., Adeola, O. and Oghazi, P. (2016) 'Investigating the path from firm innovativeness to financial performance: the roles of new product success, market responsiveness, and environment turbulence', Journal of Small Business Strategy, Vol. 26, No. 1, pp.51-68.

\section{Notes}

1 Exactly the same happens with Property Tax, since most incubators are exempted from its payment.

2 The acronym BICs stands for (European) Business \& Innovations Centres.

3 Mentioned in Article 158.2 of the Spanish Constitution, the Interterritorial Compensation Fund is a financing instrument meant to correct economic imbalances between different territories in Spain.

4234 out of 680 spaces (offices and industrial premises) to accommodate firms were available in the incubators located in the region under analysis. 